\title{
Exposure of monocytes to heat shock does not increase class II expression but modulates antigen-dependent $\mathrm{T}$ cell
} responses

\author{
Ewa Marléthoz, Fablenne Tacchinl-Cottler'1, Murlel Jacquier-Sarlin, \\ Fiona Sinclair $r^{2}$ and Barbara S. Polla

\begin{abstract}
Allergy Unit, University Hospital and 'Department of Pathology, CMU, University of Geneva, 1211 Geneva 14, Switzerland

2Present address: Universty Department of Surgery, Western Infirmary, 44 Church Street, Glasgow
\end{abstract} \\ G11 6NT, UK
}

Key words: antigen processing, chaperones, diphtherla toxin, heat shock proteins, hsp70, MHC class II mólecules, MLR, superantigens

\begin{abstract}
Abstrect
Expression of heat shock (HS) proteins (HSP) Increases after exposure to elevated temperatures or other types of Injury, such as oxidative Injury. Because of their function as 'molecular chaperones', HSP are suggested to particlpate In antigen processing and presentation. We have prevlously reported that HS modulates antigen presentation In a human EBV-transformed B cell IIne. Here we investlgated the effects of HS on MHC class II expression and on antigen processing and presentation by human monocytes. Monocytes were lsolated from perlpheral blood of normal human volunteers, purifled by adherence, then exposed to temperatures ranging from 37 to $45^{\circ} \mathrm{C}$ for $20 \mathrm{mln}$, allowed to recover for $2 \mathrm{~h}$ at $37^{\circ} \mathrm{C}$ and used for Immunofluorescence or as antigen presenting cells In autologous and heterologous lymphocyte prollferation assays. No Increase in class II expression was detected as assessed by flow cytometry. Monocytes $\left(3 \times 10^{4}\right)$ and lymphocytes $\left(1 \times 10^{5}\right)$ were co-cultured for 5 days in the presence of several antigens [diphtheria toxold, tetanus toxold or purified peptide derivative (PPD)] and labeled with $1 \mu \mathrm{Cl}\left[{ }^{3} \mathrm{H}\right.$ ]thymidlne for $16 \mathrm{~h}$. Pre-exposure to HS $\left(44^{\circ} \mathrm{C}\right)$ significantly $(P<0.001)$ Increased T cell responses to diphtherla toxold, whereas the effect on the responses to other antlgens (tetanus toxold or PPD) were not signlficant. HS did not incresse heterologous $T$ cell responses nor $T$ cell proliferation induced by the non-processed superantigens such as staphylococcal enterotoxin $B$. The effect of HS was Inhlbited by actinomycin B and thus appeared dependent upon HSP 8ynthesis. HSP-mediated Increases in antigen processing may potentlate the ongolng immune response at Inflammatory sites.
\end{abstract}

The heat shock (HS) response is an ubiquitous response to cellular stress characterized by the increased expression of HS or stress proteins (HSP). HSP are usually classified into families according to their apparent molecular weight. The hsp70 family contains several members of mol. wt ranging from 68 to $74 \mathrm{kDa}$, expressed constitutively (cognates) and/or increased or induced after exposure to HS or a number of other types of injury, including oxidative injury $(1,2)$. Hsp70 molecules function as 'molecular chaperones' (3) and participate in the proper folding, assembly and sorting of nascent peptides, as well as in transmembrane transport. Members of the hsp70 family may play a role in antigen processing and presentation (4-6). Indeed, the hsp70 family contains the clathrin uncoating ATPase $(7,8)$; other members of the hsp70 family participate in targeting cytosolic proteins to the lysosomal compartment [prp73, (9)] or in the intracellular transport of selected antigens [peptide binding protein (PBP72-74; 5,6)]. Furthermore, endoplasmic resident stress proteins can associate with HLA-DR molecules in invariant chain-negative BALB/C 3T3 cells transfected with the HLA.DR gene (10).

Correspondence to B. S Polla 
We previously found that HS increases class II expression and presentation of peptides in an HLA-DR1 human B cell line (11). The increase in class II expression was associated with an increased ability to stimulate autologous and alloreactive $T$ cell clones and to present peptide to an influenza-specific $T$ cell clone. HS also increased the ability of this B cell line to present whole influenza. Other studies reported no significant increase in class II expression following HS in monocytes (12) or in the

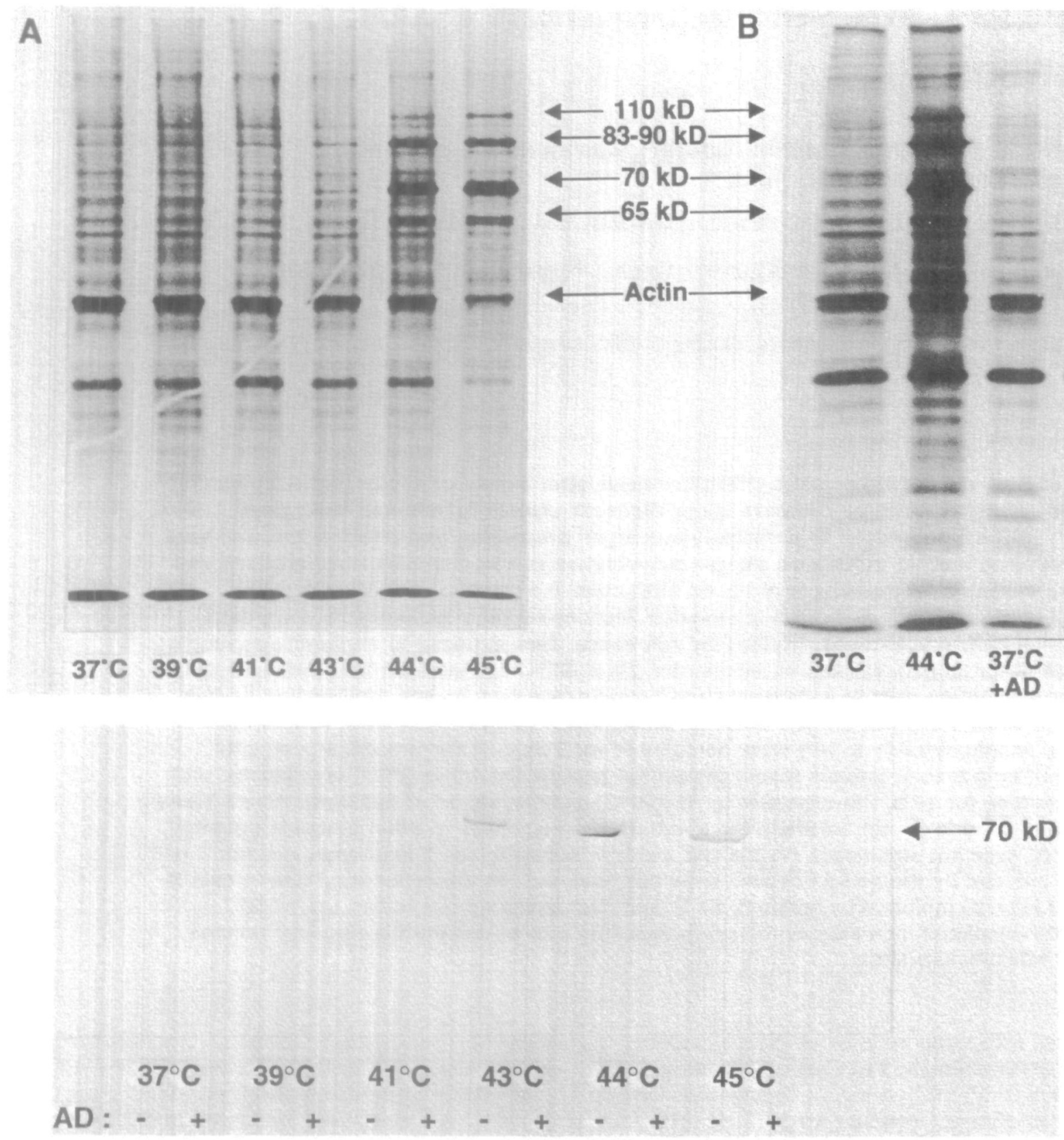

Fig. 1. (A) Human monocytes were exposed to the indicated temperatures for $20 \mathrm{~min}$, allowed to recover for $2 \mathrm{~h}$, labeled with $\left[{ }^{35} \mathrm{~S}\right] \mathrm{methionine}$ $(9 \mu \mathrm{Ci} / \mathrm{ml})$ for $90 \mathrm{~min}$, washed and lysed in SDS buffer. Aliquots corresponding to equal cell numbers were electrophoresed on slab gels with $10 \%$ polyacrylamide. Constitutive hsp 70 was detectable at $37^{\circ} \mathrm{C}$, whereas the inducible HSP, $65,70,90 \mathrm{kDa}$, were observed after exposure to 44 and $45^{\circ} \mathrm{C}$. The decrease in normal protein synthesis only occurred after exposure of monocytes to $45^{\circ} \mathrm{C}$. (B) Actinomycin D $(5 \mu \mathrm{g} / \mathrm{ml})$ was added 10 min before HS to parallel cultures and removed at the end of HS. The cells were then processed as described in (A). The 65, 70 and $90 \mathrm{kDa} H S P$ induced after exposure to $44^{\circ} \mathrm{C}$ were not detectable anymore when actinomycin $\mathrm{D}$ had been added, whereas total protein synthesis was unaltered. (C) Actinomycin D $(5 \mu \mathrm{g} / \mathrm{ml})$ was added 10 min before HS to parallel cultures and removed right at the end of HS. The cells were then processed as described in (A) and Western blot performed. Equal amounts of proteins for each sample were electrophoresed and transferred to nitrocellulose paper (26). The membrane was saturated with casein-contaning buffer for $2 \mathrm{~h}$ and hybridized with a mouse monoclonal anti-human hsp70 antibody (Stress $\mathrm{Gen}$ ). Bound hsp70 antibody was revealed with anti-mouse lgG peroxidase conjugated (Sigma) in the presence of $\mathrm{H}_{2} \mathrm{O}_{2}$ and 4-chloro-1. naphthol (Sigma). The $70 \mathrm{kDa}$ HSP induced after exposure to 43,44 and $45^{\circ} \mathrm{C}$ were no longer detectable when actinomycin D had been added. 
Epstein - Barr virus-transformed B cell line (EVB - LCL) (13).

In the present study we analysed the effects of HS on class II expression and antigen presentation and processing in normai human peripheral blood monocytes.

Celis were prepared and processed in RPMI 1640 (Gibco, Passley, UK) with 10\% FCS (Kibutz Beth, Heamek, Israel), 1\% glutamine (Gibco) and $25 \mathrm{mM}$ HEPES (Gibco) [HEPES medium $(\mathrm{HM})$ ] and cultured in RPMI 1640 with $20 \%$ pooled human male AB serum (Centre de Transfusion sanguine, Annemasse, France) and $1 \%$ glutamine (Gibco) [(complete medium (CM)]. Peripheral blood mononuclear cells were isolated by gradient centritugation and monocytes purified as previously described (14), recovered, washed with PBS (Gibco), re-suspended in HM and then sampled. Selected samples were exposed for $20 \mathrm{~min}$ to temperatures ranging from 37 to $45^{\circ} \mathrm{C}$ as described previously (14), whereas control samples were maintained at $37^{\circ} \mathrm{C}$. After $\mathrm{HS}$, the cells were washed twice with PBS, allowed to recover for $2 \mathrm{~h}$ at $37^{\circ} \mathrm{C}$, then counted again and re-suspended in $\mathrm{CM}$ or in CM without methionine at $1 \times 10^{8} \mathrm{cells} / \mathrm{ml}$. Neither HS (up to $44^{\circ} \mathrm{C}$ ) nor actınomycin $D$ had any effect on cell viability as tested by trypan blue exclusion and protein synthesis.

In the monocytes, maximal hsp 70 synthesis without inhibition of normal protein synthesis was obtained after exposure to $44^{\circ} \mathrm{C}$ as shown by metabolic labeling with $\left[{ }^{35} \mathrm{~S}\right]$ methionine (sp. act. $1145 \mathrm{Ci} / \mathrm{mmol}$, Amersham International, Amersham, UK) (Fig. 1A). We thus elected this temperature for most subsequent studies. As previously reported in human neutrophils (15), the transcriptional inhibitor actinomycin D (Sigma Chemicals Company, St Louis, MO); final concentration $5 \mu \mathrm{g} / \mathrm{mI}$ ), added $10 \mathrm{~min}$ before and during the HS, selectively prevented HSP induction by $\mathrm{HS}$ without altering normal protein synthesis (Fig. 1B), as shown for hsp70 in Fig. 1C (Western blot performed with mouse monoclonal anti-human inducible hsp70 from Stress Gen, San Francisco, CA and anti-mouse lgG peroxidase
A

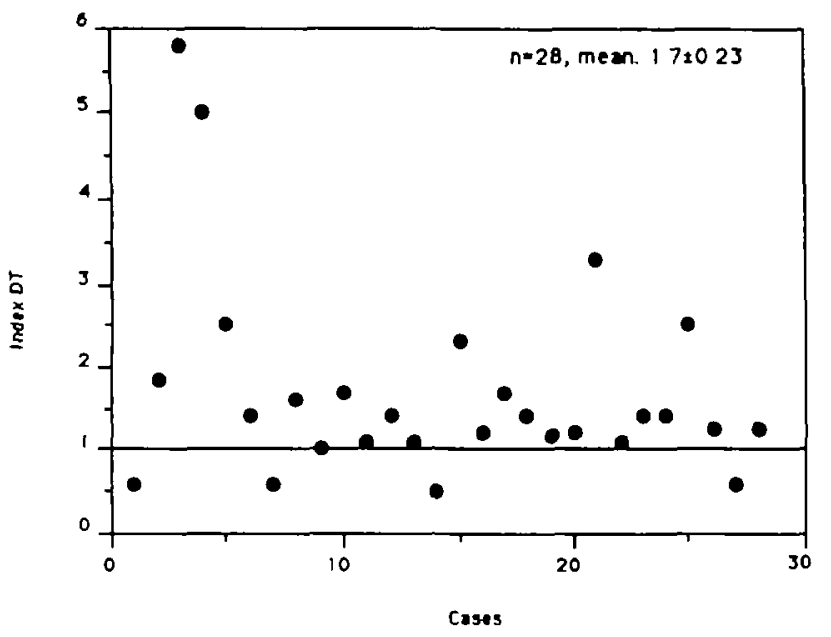

B

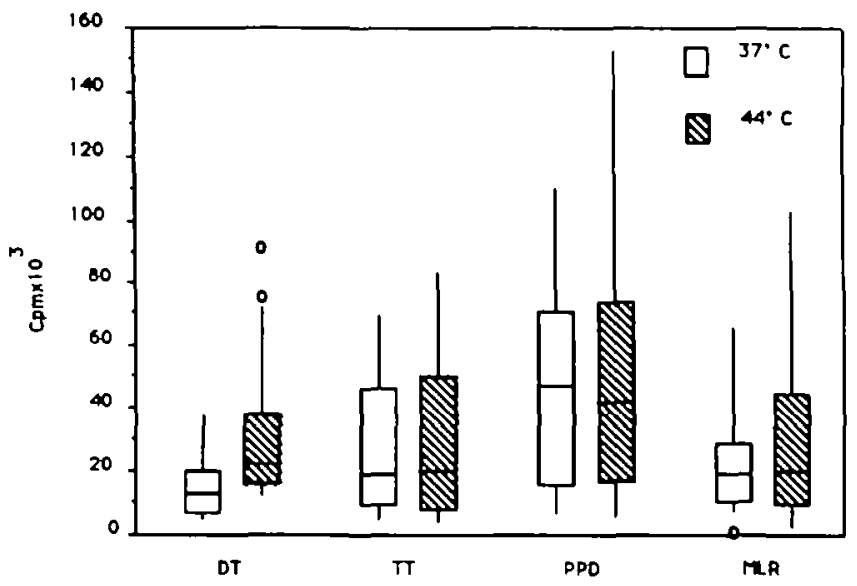

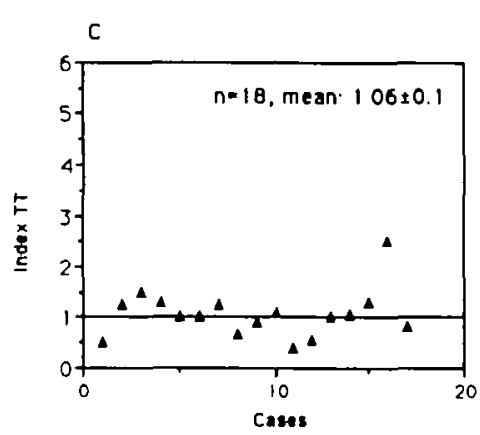
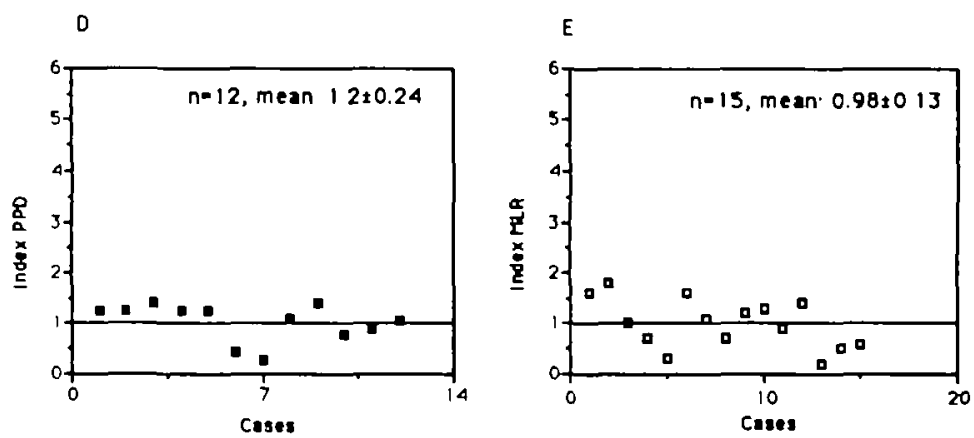

Fig. 2. Immunofluorescence analysis of cell surtace class II HLA-DR expression in monocytes exposed or not to HS. Some $2 \times 10^{5}$ cellshwell were plated onto a 96-well plate in $100 \mu$ PBS with $5 \%$ human serum and $0.01 \%$ azide. After HS, the plate was centrifuged and the cells stained with $5 \mu \mathrm{g}$ mouse anti-human DR antibody (CR3/43, L243, XD5.A11) for $30 \mathrm{~min}$ at $4^{\circ} \mathrm{C}$. The cells were washed three times in PBS, and stained with $2 \mu \mathrm{g}$ rabbit anti-mouse FITC conjugated antibody (DAKO) for 30 mIn at $4^{\circ} \mathrm{C}$ The negative control was obtained by staining the cells with rabbit anti-mouse FITC conjugated antibody (DAKO) and the positive controf was obtained by staining the cells with mouse antı human CD, ${ }_{14}$ antibody (DAKO). The cells were anaiysed on a Epics •-Profile Il Counter (Coulter, Miamı, FL) provided with an argon laser (488 nm), calibrated by computer, and optimized for sensitivity and resolution with fluorospheres (Immuno-Check, PN 6603487, Epics Division). The data were analysed using Epics - Profile Version 2.0 Software. Dead cells and lymphocytes were excluded on the basis of forward and sideward scatter. 10,000 events were analysed. PBMC not heated (plain line) and heated (boid line) were stained with different mAbs: (A) rabbit anti-mouse FITC conjugated antibody; (B) anti-CD14 antibody; (C) the mouse anti-human class I monoclonal antibody WR6/32 (M736 DAKO, Denmark); (D) the mouse anti-human DR $\alpha \beta$ monoclonal L243 (kindly provided by $E$ O. Long. Rockville, MD); (E) mouse antu-human class II $\beta$ chain monoclonal antibody XD5:A11 (kindly provided by E O. Long, Rockville, MD); and ( $F$ ) anti-class II $\beta$, CR3/43, a mouse anti-human class II $\beta$ chain monoclonal (M775, DAKO). Cells were washed and antibody binding revealed with FITC rabbit ant/-mouse antibody No significant difference was observed after HS. 
conjugated Fab from Sigma). This inhibition of HSP synthesis was thereafter used to distinguish possible physical effects of elevated temperature on cell metabolism from effects relating to HSP themselves (15).

As previously reported by others in these cells (12), no increase in class 11 expression was detectable $2 \mathrm{~h}$ after HS using FACS analysis (Fig. 2) (for detailed methods see Fig. 2 legend). Following HS, class II molecules (but not control molecules such

Table 1. Effects of HS on lymphocyte proliferative response to mitogen (PHA), to antigen (DT, TT, PPD) or to staphylococcal antigen (SEB)

\begin{tabular}{lrrrl}
\hline & $n$ & \multicolumn{2}{l}{$\begin{array}{l}{[3 \mathrm{H}] \text { Thymidine incorporation }} \\
\left.\text { (c.p.m. } \times 10^{-3}\right) \pm \text { SEM }\end{array}$} & $P$ \\
\cline { 3 - 4 } & & $37^{\circ} \mathrm{C}$ & $44^{\circ} \mathrm{C}$ & \\
\hline Control & 40 & $2 \pm 0.3$ & $2 \pm 0.3$ & NS \\
PHA & 40 & $35 \pm 6.0$ & $32 \pm 4.0$ & NS \\
DT & 28 & $14 \pm 2.0$ & $23 \pm 4.0$ & 0.0009 \\
TT & 18 & $27 \pm 5.0$ & $29 \pm 6.0$ & NS \\
PPD & 12 & $46 \pm 10.0$ & $49 \pm 13.0$ & NS \\
MLR & 15 & $23 \pm 5.0$ & $22 \pm 5.0$ & NS \\
SEB & 5 & $11 \pm 2.0$ & $13 \pm 3.0$ & NS \\
\hline
\end{tabular}

as CD14) clustered in patches on the cell membrane, in a manner reminiscent of the capping of antibody molecules, suggesting redistribution of class II molecules secondary to membrane alterations (16). The results previously obtained in B cells therefore could not be extended to human monocytes and thus in these latter cells a positive effect of HS may relate to increased processing rather than presentation. Along these lines, we tested the effects of $\mathrm{HS}$ on processing-independent $\mathrm{T}$ cell activation by super- or allo-antigens.

We performed mixed lymphocyte reaction (MLR) experiments with cells from 15 distinct donors. Non-adherent mono-nuclear cells were applied to nylon wool columns (Biotest Diagnostics, Dreieich, Germany) previously wetted with $3 \mathrm{ml} \mathrm{HM}$ for $1 \mathrm{~h}$. Cells were slowly eluted in $\mathrm{HM}$, washed and re-suspended in $\mathrm{CM}$ at a final cell concentration of $1 \times 10^{6} / \mathrm{ml}$. Lymphocytes were not exposed to HS. After preliminary studies determined optimal monocytes: lymphocyte ratios in control experiments, $3 \times 10^{4}$ monocytes and $1 \times 10^{5}$ heterologous lymphocytes were co-cultured in 96-well flat-bottom tissue culture plates (Costar, Cambridge, UK) and antigens or mitogens were added. Each condition was tested in quintuplicate. On day $5,\left[{ }^{3} \mathrm{H}\right]$ thymidine ( $1 \mu \mathrm{Ci} /$ well) (sp. act. $2 \mathrm{Ci} / \mathrm{mmol}$; Amersham) was added for $16 \mathrm{~h}$. Cells were harvested and lysed (Skatron automatic cells harvester, Skatron Instruments, Lier, Norway), and labeled DNA counted in scintillation vials using a Beckman Liquid Scintillation

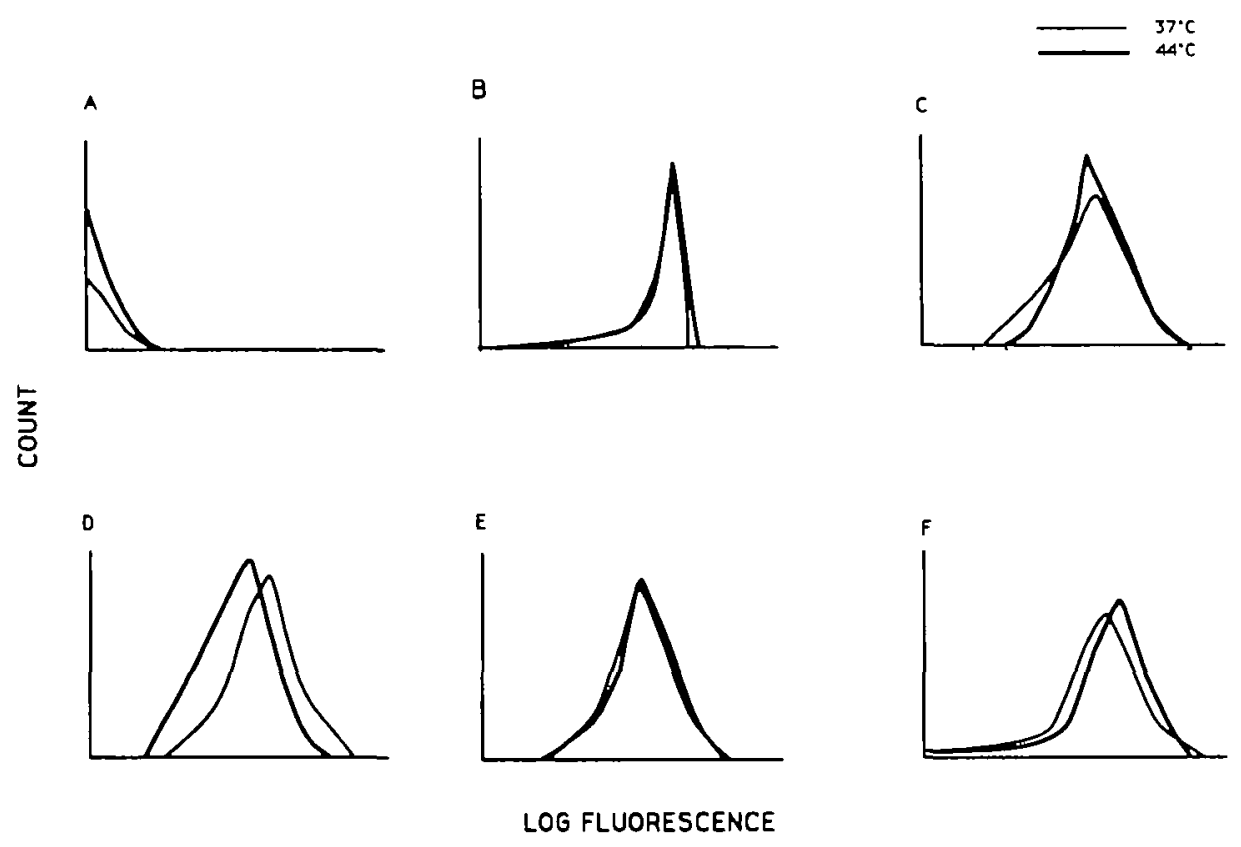

Fig. 3. Proliferation assays: $1 \times 10^{5} \mathrm{~T}$ lymphocytes were co-cultured in the presence of $3 \times 10^{4}$ autologous monocytes maintained at $37^{\circ} \mathrm{C}$ or exposed to $44^{\circ} \mathrm{C}$ and $\left[{ }^{3} \mathrm{H}\right]$ thymidine incorporation determined at day 5 . The cells co-cultured in the RPMI $+20 \%$ human serum $+1 \%$ glutamine and: (A) DT at $8900 \mathrm{U} / \mathrm{ml}$; (C) TT at $525 \mathrm{U} / \mathrm{ml}$; (D) PPD at $7.5 \mu \mathrm{g} / \mathrm{ml}$; or (E) MLR. On day 5, [ $\left.{ }^{3} \mathrm{H}\right]$ thymidine was added for $16 \mathrm{~h}$, then the cells were harvested. The results are expressed as the proliferative index:

$$
\frac{\text { c.p.m. antigen at } 44^{\circ} \mathrm{C}-\text { c.p.m. control at } 44^{\circ} \mathrm{C}}{\text { c.p.m. antigen at } 37^{\circ} \mathrm{C}-\text { c.p.m. control at } 37^{\circ} \mathrm{C}}
$$

( $A, C, D$ and E) Preexposure to $H S\left(44^{\circ} \mathrm{C}\right)$ increased the stimulation index for DT (A) but had no significant effect on $T$ cell responses to $\Pi$ (C), or to PPD (D), or in MLR (E). (B) Pre-exposure to HS $\left(44^{\circ} \mathrm{C}\right)$ significantly increased DT-dependent T cell proliferative responses but not TT, PPD or MLR dependent T cell proliferative responses (B). The results are expressed in c.p.m. $\times 10^{3}$ and represented as a box plot: a rectangle parallel to one axis, with its two ends at the upper and lower quartiles; the median or the middle value is the line cutting the box; lines extended from the ends show the smallest and the largest observation; most extreme values are shown as individual observations. Only the median DT $44{ }^{\circ} \mathrm{C}$ is increased when compared with the control. 
Counter (Beckman LS 7500). The experiments in which the negative controls (monocytes heated or not with autologous lymphocytes, without antigen nor mitogen) were $>5000$ c.p.m. were dismissed $\left[{ }^{3} H\right]$ Thymıdine incorporation into monocytes or lymphocytes alone was <500 c.p.m In these and all subsequent experiments heated and control samples were compared by the Wilcoxon signed-rank test.

HS did not affect T cell responses in MLR (Table 1, Fig. 3E), except at the higher temperatures, at which there was a decline in $T$ cell proliferation. Others have reported previously that exposure of human or murıne antigen presenting cells (APC) to higher $\left(45^{\circ} \mathrm{C}\right)$ or to lower temperatures $\left(43^{\circ} \mathrm{C}\right)$ but for prolonged periods of time $(3 \mathrm{~h})$ abolishes presentation ability $(12,13,17)$. We found similarly that when the allogeneic APC were heated to $45^{\circ} \mathrm{C}$ for $20 \mathrm{~min}$ lymphocyte proliferation was abolished or greatly reduced (data not shown). These findings could relate to (i) nonspecific membrane alterations induced by HS; (ii) a decrease in expression and/or production of cytokines important for presentation such as membrane or secreted interleukin 1 (12); or (iii) an HS-induced inhibition of the synthesis of proteins Involved in antigen processing, presentation or internalization via specific receptors (18).

Similarly, we compared the effect of HS on the autologous T cell response to superantigens such as staphylococcal enterotoxin B (SEB; final concentration $10^{-6} \mathrm{mg} / \mathrm{ml}$, Sigma Chemicals Company), which do not appear to require processing although they need to associate with MHC class II molecules (19). Preexposure of APC to $44^{\circ} \mathrm{C}$ did not affect lymphocyte proliferation in response to SEB (Table 1).

In contrast, pre-exposure of the monocytes to HS resulted in enhanced T cell responses to diphtheria toxoid (DT), $(8900 \mathrm{U} / \mathrm{ml}$; Institut Pasteur-Mérieux, Lyon, France) (Table 1, Fig. 3A and B). The ability of the cells to induce autologous $T$ cell response to nominal antigen was compared at 37 and $44^{\circ} \mathrm{C}(\mathrm{HS})$ in 40 distinct experiments. Whereas HS altered neither basal levels of $\left[{ }^{3} \mathrm{H}\right]$ thymidine incorporation into $\mathrm{T}$ cells (negative control) nor T cell proliferation in response to PHA $(0.75 \mu \mathrm{g} / \mathrm{ml}$; Wellcome Diagnostics, Dartford, UK) (positive control) (Table 1), T cell proliferation in response to DT was significantly increased when the APC were pre-exposed to $44^{\circ} \mathrm{C}(n=28$; Table 1, Fig. $3 \mathrm{~A}$ and $B$ ). This increase could be blocked by actinomycin $D$. As shown in Fig. 4, the drug had no effect on lymphocyte proliferation when the APC were maintained at $37^{\circ} \mathrm{C}$, but prevented the HS-induced increase in T cell responses to DT. These experiments support the hypothesis that increased levels of HSP within the APC play a role in the observed increases in T cell responses to DT.

The intracellular pathways for processing and presentation of exogenous antigens is assumed to involve antigen proteolysis, binding to MHC class II molecules and translocation of the resulting complex across membranes. Increasing evidence suggests that the delivery of processed peptides to MHC class II molecules requires peptide transporters, as is the case for MHC class I (20). This hypothesis is supported by the fact that synthetic antigenic peptides and purfied MHC class II molecules incorporated into lipid bilayers are sufficient to activate $T$ cells, whereas the peptide concentration required for presentation in vivo is considerably lower than required in vitro (21). Peptide transporters such as PBP72/74 or other members of the HSP families could participate in the association between peptide and class II (4) as an equivalent of the invariant chain. Chaperones may also take part in the biosynthesis and exocytosis of MHC class II molecules themselves (20), scavenge peptides from degradative compartments, prevent complete proteolysis or concentrate peptides for binding to MHC class II molecules $(4-6)$. Several genes coding for members of the hsp70 family have been mapped within the MHC, as is the case for transporter molecules such as the RING genes (22).

We extended these studies to other vaccination antigens, but induction of HSP within the APC did not significantly increase $T$ cell responses to either tetanus toxoid $(\pi$; Institut PasteurMérieux. Lyon, France at $525 \mathrm{U} / \mathrm{ml}$ ) nor purified peptide derivative (PPD, $7.5 \mu \mathrm{g} / \mathrm{ml}$; Statens Serum Institut, Copenhagen, Denmark) (Table I, Fig. $3 \mathrm{C}$ and $\mathrm{D}$ ). It thus appears that there may be some antigen specificity in the HS-induced modulation of accessory cell function.

Several aspects of DT may explain this selectivity. The toxin is synthesized as a single polypeptide chain ( $\mathrm{mol} . \mathrm{wt}=58 \mathrm{kDa}$ ), further cleaved in two disulfide-linked fragments. Fragment $A$ $(-21 \mathrm{kDa})$ is enzymatically active and by ADP-ribosylation inactivates elongation factor 2 ; fragment $B(\sim 37 \mathrm{kDa})$ binds to specific receptors at the cell surface (23). After binding to its receptor, the toxin is internalized by endocytosis from coated pits (24). Thus, a first hypothesis to explain the HS-induced selective increase in DT processing relates to the fact that the clathrin uncoating ATPase is a member of the hsp 70 family. The clathrin uncoating ATPase, however, is a cognate protein with moderate responsiveness to HS Second, the small size of DT may facilitate its binding to chaperones. However, $T$ cell responses to small (30 amıno acid) $T$ peptides (kindly provided by G. Coarradin, Lausanne, Switzerland) did not appear to be modulated by HS (unpublished data), indicating that peptide size may not be a major determinant for the effects of HS. Third, the selective increase in T cell responses to DT may relate to the fact that basal $T$ cell responses to this antigen were usually lower than to $\Pi$

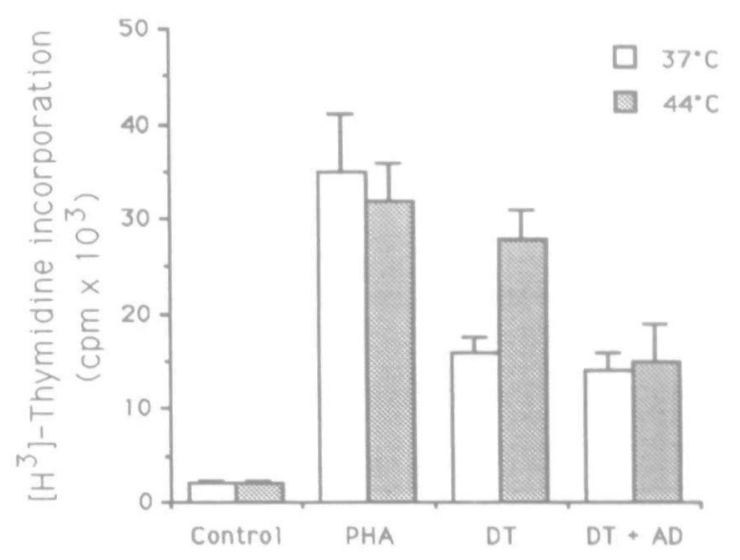

Fig. 4. Actinomycin $D$ inhibits the increase in the $T$ cells proliferation induced by the HS in the DT stimulated APC T lymphocytes $\left(1 \times 10^{5}\right)$ were co-cultured in the presence of $3 \times 10^{4}$ autologous monocytes maintained at $37^{\circ} \mathrm{C}$ or exposed to $44^{\circ} \mathrm{C}$ and $\left[{ }^{3} \mathrm{H}\right]$ thymidine incorporation determined in six proliferation assays performed with or without actinomycin D $(5 \mu \mathrm{g} / \mathrm{ml})$ added $10 \mathrm{~min}$ before HS. The results are expressed as c.p.m. $\times 10^{3}$. Bars represent means \pm SEM. The HSinduced increase in lymphocyte proliferation was significantly decreased in the presence of actinomycin $D(n=6, P \leq 0.05)$. 
or PPD. However, the HS-induced increase in DT-specific T cell proliferation was essentially observed in the cases with the highest levels of $T$ cell proliferation in response to DT at $37^{\circ} \mathrm{C}$, and there was no significant effect of HS in titration experiments with lower concentrations of $\pi$ (unpublished data).

Finally, HSP may selectively bind DT and thus efficiently chaperone this antigen through the cell or protect immunogenic DT fragments from complete proteolysis. The selectivity for a given antigen may relate to the biochemical properties of HSP, as is the case for $\pi$ chaperoned by C3b (25). The observation that HSP partially prevented the inhibition of DT processing by chloroquine (unpublished data) suggests that a member of the HSP family (prp73?) directly targets DT into the lysosomes or the processing vesicle, allowing its processing even in the presence of drugs preventing lysosome fusion and antigen processing in the acidification compartment. However, there is no KFERQ sequence (the prp73-binding amino acid sequence) (9) in DT fragment $A$.

The data presented here provide further support to the concept that HSP play a role in antigen processing and presentation. HSPmediated amplification of T cell responses to certain antigens may be of relevance to the ongoing immune response in inflammatory sites, where HSP may be up-regulated in monocytes by cytokines or reactive oxygen species.

\section{Acknowledgements}

We are grateful to Laurie Glimcher and Jean-Pierre Liautard for helpful suggestions and critical review, to Amos Bairoch for sequence research, to $G$. Corradin for $T T$ peptides, to E. O. Long and $E$. Roosnek for antibodies, to D. Wohlwend for assistance in FACS analysis and to Sibyl Baladi for technical help. This work was supported by the Swiss National Research Foundation grant no. 32-028645.90 to BSP. MJ was supported by a grant from ARC.

\section{Abbreviations}

APC

CM

DT

HM

HS

HSC

HSP

MLR

PBP

PPD

SEB

TT

antigen presenting cells
complete medium
diphtheria toxoid
HEPES medium
heat shock
heat shock cognate
heat shock proteins
mixed lymphocyte reaction
peptide binding protein
purified peptide derivative
staphylococcal enterotoxin B
tetanus toxoid

\section{References}

1 Hightower, L. E. 1991. Heat shock, stress proteins, chaperones and proteotoxicity. Cell 66:191.

2 Kantengwa, S., Donati, Y. R. A., Clerget, M., Maridonneau-Parini, I., Sinclair, F., Mariethoz, E., Perin, M., Rees, A. D. M., Slosman, D. O. and Polka, B. S. 1991 Heat shock proteins: an autoprotective mechanism for inflammatory cells? Sem. Immunor. 3.49.

3 Ellis, R. J. and van der Vies, S. M. 1991. Motecular chaperones. Annu. Rev. Biochem. 60:321.

4 DeNagel, D. C. and Pierce, S. K. 1992. A case for chaperones in antigen-processing. Immunol. Today 13:86.

5 VanBuskirk, A., Crump, B. L., Margoliesh, E. and Pierce, S. K. 1989 A peptide binding protein having a role in antigen presentation is a member of the HSP70 heat shock family. J. Exp. Med. 170:1799.

6 Manara, G C, Sansoni, P., Badialı-De Gıorgı, L., Galınella, G., Ferrari, C., Brianti, V., Fagnoni, F F., Reugg, C. L., de Panfilis, G. and Pasquinelli, G. 1993. New insights suggesting a possible role of a heat shock protein $70 \mathrm{kD}$ family-related protein in antigen processing/ presentation phenomenon in humans. Blood 82:2865

7 Chappell, T G, Welch, W J., Schlossman, D. M., Palter, K. B., Schlesinger, M. J. and Rothman, J. E. 1986. Uncoating ATPase is a member of the 70 kilodalton family of stress proteins. Cell 45:3.

8 Ungewickell, E. 1985. The 70-kd mammalian heat shock proteins are structurally and functionally related to the uncoatng protein that reteases clathrin triskelia from coated vesicles. EMBO J. 4:3385.

9 Chiang, H.-L., Terlecky, S. R., Plant, C. P. and Dice, J. D. 1989. A role for a 70 kilodalton heat shock protein in lysosomal degradation of intracellular protens. Science 246:382.

10 Schaiff, W. T., Hruska, K. A., Jr, McCourt, D W., Green, M. and Schwartz, B. D. 1992. HLA-DR associates with specific stress proteins and is retained in endoplasmic reticulum in invariant chain negative cells. J. Exp. Mod. 176:657

11 Rees, A. D. M., Donati, Y. R. A., Lombardi, G., Lamb, J., Polla, B. S. and Lechler, R. 1991. Stress induced modulation of antigenpresenting cells function. Immunology 74:386.

12 Goeken, N. E., Ballas, Z. K. and Staggs, T. S. 1986. Atteration of human accessory cells function by heat treatment: role of IL-1 and class II molecules. Human Immunol. 16:234.

13 Loertscher, R., Abbud-Filho, M., Leichtman, A. B., Ythier, A A., Williams, J. M., Carpenter, C. B. and Storm, T. B. 1987. Differential effect of gamma-irradiated and heat-treated lymphocytes on $T$ cell activation and interleukin-2 and interleukin-3 release in human mixed lymphocyte reaction. Transplantation 44:673.

14 Polla, B. S., Healy, A. M., Wojno, W. C. and Krane, S. M. 1987 Hormone $1 \alpha, 25$-dihydroxyvitamin $D_{3}$ modulates heat shock response in monocytes. Am. J. Physiol. 252:C641.

15 Maridonneau-Parini, I., Malawista, S. E., Stubbe, H., Russo-Marie, F. and Polla, B. S. 1993. Heat-shock proteins in human neutrophils. superoxide generation is inhibited by a mechanism distinct from heatdenaturation of NADPH oxidase and is protected by heat shock proteins in thermotolerant cells $J$ Cell. Physiol. 156:204.

16 Polla, B. S., Mariethoz, E. and Rees, A. D. M. 1992 More evidence for a case for chaperones in antigen processing. Immunol. Today 13:421.

17 Mandell, R. B., Hank, J. A., Chen, B. P., Robins, H. I. and Sondel, P. M. 1987. Differential antigen presentation by heat-treated peripheral blood mononuclear colls and Epstein - Barr virus transformed lymphoblastold cell lines (EVB-LCL): heated EBV-LCL present alloantigen and soluble antigen but are deficient in the stimulation of autologous EBV-LCL primed T cells. Human Immunol. 19:163.

18 Kakiuchi, T., Watanabe, M., Hozumi, N. and Nariuchi, H. 1990. Differential sensitivity of a specific and non specific antigen-presentation by $B$ cells to a protein synthesis inhibitor. J. Immunol. 145:1653.

19 Fraser, J. D. 1989. High-affinity binding of Staphytococcal enterotoxins $A$ and $B$ to HLA-DR. Nature $339 \cdot 221$.

20 Parham, P. 1989. MHC molecules, a profitable lesson on heresy. Nature 340:426.

21 Buus, S., Sette, A., Cołon, S. M., Janıs, D. M. and Gray, H. M. 1987. Isolation and characterization of antigen - la complexes involved in T cell recognition. Cell 47:1071.

22 Sargent, C. A., Dunham, I., Trowsdale, J. and Campell, R. D. 1989. Human major histocompatibility complex contains genes for the major heat shock protein HSP70. Proc. Natt Acad. Sci. USA 86:1968.

23 Olsen, S. Moskaug, J. O., Stenmark, H. and Sandvig, K. 1990 Translocation of diphtheria toxin to the cytosol and formation of cation selective channels. J. Physiol. (Paris) 84.191.

24 Morris, R E. Gerstein, A. S., Bonventre, P F. and Saelınger, C. B. 1985 Receptor mediated entry of diphtheria toxin into monkey kıdney (Vero) cells: electron microscopic evaluation. Infect. Immunot. 50:721.

25 Jacquier, M. R., Gabert, F., Villiers, C. L. and Colomb, M. G. 1993. Disulfide linkage between $\mathrm{C} 3 \mathrm{~b}$ and tetanus toxın on tetanus toxinspecific EBV transformed B cells. J. Immunol. 150:4253.

26 Towbin, H., Staething, T. and Gordon, J. 1979. Electrophoretic transfer of proteins from polyacrylamide gels to nitrocellulose sheets: procedure and some applications. Proc. Natf Acad. SCi. USA 76:4350. 